\title{
Nutritional, Physicochemical and Microbial Quality of Ultrasound-Treated Apple-Carrot Juice Blends
}

\author{
Jingfei Gao, H. P. Vasantha Rupasinghe
}

Department of Environmental Sciences, Nova Scotia Agricultural College, Nova Scotia, Canada.

Email: vrupasinghe@nsac.ca

Received November $30^{\text {th }}, 2011$; revised December $30^{\text {th }}, 2011$, accepted January $8^{\text {th }}, 2012$

\begin{abstract}
Three different apple-carrot juice blends (60:40, 75:25 and 90:10, v/v) were prepared and treated with ultrasound with comparison to the conventional thermal pasteurization. Total aerobic viable count (TAC) were significantly lower in juice blends with lower $\mathrm{pH}$ (apple-carrot ratio of $90: 10, \mathrm{v} / \mathrm{v}$ ) than the blends with higher $\mathrm{pH}$ after one month storage at $4^{\circ} \mathrm{C}$. TAC were similar in ultrasound-treated and thermal pasteurized juice blends. Changes of turbidity of juice during storage followed the same pattern of TAC. Other juice quality parameters such as color, $\mathrm{pH}$, titratable acid, total soluble solids, antioxidant capacity and beta-carotene did not change significantly during the storage period. The results suggest that ultrasound treatment has a potential to use as an alternative non-thermal technique for traditional thermal pasteurization process for maintaining the quality of beverages prepared from fruit and vegetable juices.
\end{abstract}

Keywords: Ultrasound; Pasteurization; Non-Thermal; Nutrition; Microbial Growth; Beta-Carotene; Antioxidant Capacity

\section{Introduction}

Carrot juice has a high nutritional value, as it is an important dietary source of carotenoids such as alpha- and beta-carotene, zeacarotene, lutein and lycopene [1]. Betacarotene, one of the most biologically active carotenoids, act as provitamin A [1]. However, preservation of carrot juice is difficult due to its low acidity which provide ideal environment for the growth of many spoilage and spore forming bacteria [2]. Acidification of carrot juice could be achieved by either fermentation or adding citric acid [2]. Blanching the carrots in acid could also improve the color of carrot juice [3]. Alternatively, blending carrot juice with acidic fruit juices such as apple juice could produce a blend with a lower $\mathrm{pH}$ that can act as a natural barrier against most microorganisms.

Thermal treatments are used for extending the shelf life of vegetable juices by inactivating microorganisms and enzymes [4]. However, heat processing often induces undesirable changes that account for nutrient loss, colour alteration as well as sensory property changes $[4,5]$. Nonthermal methods such as ultrasound treatment have been proposed as alternatives for thermal pasteurization so that the changes of flavor and nutritional value can be minimized during processing $[4,5]$. Compared with the diagnostic ultrasound, a lower frequency range of 20 to 100 $\mathrm{kHz}$ and a higher sound intensity of 10 to $1000 \mathrm{~W} / \mathrm{cm}^{2}$ is used for microbial control in food applications $[4,6]$. Ultrasound inhibits and destroys microorganisms due to the phenomenon of cavitation, the generation and collapse of micro bubbles results in high localized temperatures and pressure causing disruption of cell walls, membranes and DNA of microorganisms $[7,8]$. Ultrasound has been identified as a potential technology to meet the FDA requirement of a $5 \log$ colony forming units (CFU) reduction in pertinent microorganisms found in fruit juice [7] and sufficient to inactivate food borne spoilage microorganisms, such as Saccharomyces cerevisiae, pertinent to fruit juice [4].

The specific objectives of this study were to examine effects of ultrasound treatment with comparison to the thermal pasteurization on the changes in physicochemical quality attributes, beta-carotene content and antioxidant capacity of carrot juice acidified with three different levels of apple juice.

\section{Materials and Methods}

\subsection{Juice Sample Preparation}

Carrots and "McIntosh" apples were purchased from a local market. Unblemished apples and carrots were selected, washed and processed for juices separately using a commercial juice extractor (Breville, Elite 800 JEXL, Breveill, USA). 


\subsection{Ultrasound Treatment}

A $1000 \mathrm{~W}$ ultrasonic bath (Model 750D, VWR International Ltd., Leighton Buzzard, UK) was used for ultrasound treatment. Juice samples were processed at a constant frequency of $20 \mathrm{kHz}$ for $10 \mathrm{~min}$ at $25^{\circ} \mathrm{C} \pm 1^{\circ} \mathrm{C}$.

\subsection{Thermal Pasteurization}

Juice samples were pasteurized at $98^{\circ} \mathrm{C} \pm 2^{\circ} \mathrm{C}$ for $180 \mathrm{~s}$ and immediately cooled down using cold water.

\subsection{Total Aerobic Viable Count (TAC)}

TAC of juice samples were expressed as CFU per $\mathrm{mL}$ of solution. Aliquots $(1 \mathrm{~mL})$ of serially diluted juice samples were plated onto Aerobic Count Petrifilm (3M Microbiology Products, St. Paul, MN, Canada) and incubated at $37^{\circ} \mathrm{C}$ for $48 \mathrm{~h}$ using a shaking incubator (Model Apollo HP50, San Diego, CA, USA).

\subsection{Turbidity, Colour, Brix and Titratable Acidity (TA)}

Turbidity of the treated samples was measured with a portable turbidimeter (Hellige 966, Orbeco Analytical System, Inc., Farmingdale, NY, USA). Samples (11 mL) were analyzed in triplicate by transferring to a glass vial and agitated before taking turbidity readings. Turbidity readings expressed in nephelometric turbidity units (NTU) were recorded from the turbidimeter after allowing a sample to stabilize for over $15 \mathrm{~s}$.

Colour of the juice was determined by using a reflectance colorimeter (Model CR-300, Minolta Camera Co. Ltd., Osaka, Japan) based on the $\mathrm{L}^{*}, \mathrm{a}^{*}$, and $\mathrm{b}^{*}$ values [9]. The reflectance colorimeter was standardized using a white plate; reflectance values of $X=92.30, Y=0.3137$, $\mathrm{Z}=0.3195$ were used as standards. Juice samples were placed in a dish with $3 \mathrm{~cm}$ depth on a provided white background, the measuring head was immersed in the solution and the values for $\mathrm{L}^{*}, \mathrm{a}^{*}, \mathrm{~b}^{*}$ were recorded. Hue was expressed as $a^{*} / b^{*}$, while chroma is expressed as $\left(a^{2}+b^{2}\right)^{1 / 2}[10]$.

Total soluble solids (TSS), $\mathrm{pH}$ and titratable acidity (TA) were analyzed in triplicate using previously described methods [11]. Briefly, TSS (Brix) was determined with a hand held refractometer (Model 300016, Super Scientific Ltd., Scottsdale, AZ) at room temperature. TA was measured using the semi-automated titrator (DMP 785, Metrohm Ltd., Herisau, Switzerland) at $\mathrm{pH}$ 8.2 using $0.1 \mathrm{~N} \mathrm{NaOH}$ as the titrant. The $\mathrm{pH}$ value was determined with a standardized $\mathrm{pH}$ meter (Model Accumet ${ }^{\circ}$ 10, Denver Instruments Co., Arvada, Colorado, USA). The Brix: acid ratio was also calculated and compared.

\subsection{Antioxidant Capacity}

Antioxidant capacity was measured using ferric reducing antioxidant power (FRAP) assay, which was performed according to [12] with some modifications described in [13]. Briefly, the FRAP analysis was performed by reacting $20 \mu \mathrm{L}$ of blank, standard or sample with $180 \mu \mathrm{L}$ FRAP solution in COSTAR 96-well clear polystyrene plates (Thermo Fisher Scientific Inc., Waltham, MA) using FLUO star OPTIMA plate reader with an incubator and injection pump (BMG Labtech, Durham, NC). FRAP values were expressed as mmol Trolox equivalence (TE)/ $100 \mathrm{~mL}$ of juice sample.

\subsection{Beta-Carotene Content}

Beta-carotene content was estimated following the procedure of [1]. Twenty-five milligrams of beta-carotene was weighed and dissolved in $2.5 \mathrm{~mL}$ of chloroform and diluted to $250 \mathrm{~mL}$ with petroleum ether. Further, this solution was diluted with petroleum ether. The final concentrations of standards were $2,10,20,30,40$ and $50 \mathrm{mg} \cdot \mathrm{L}^{-1}$. The absorbance was measured at $452 \mathrm{~nm}$ using 96-well microplates in the FLUOstar OPTIMA plate reader (BMG Labtech, Durham, NC, USA) using 3\% of acetone in petroleum ether as blank. The beta-carotene content in the juice sample was calculated using the standard curve.

\subsection{Experimental Design}

For statistical analysis, a completely randomized design was used with a factorial experiment design of two different treatments (ultrasound and pasteurization) and three different apple-carrot juice blends (60:40, 75:25 and 90:10, $\mathrm{v} / \mathrm{v})$ and two different stored temperatures $\left(4^{\circ} \mathrm{C}\right.$ and room temperature $\left.\left(23^{\circ} \mathrm{C} \pm 1^{\circ} \mathrm{C}\right)\right)$ and three sample replicates per treatment. These were separated using the two factor repeat measures, least significant means separation with statistically significant differences at $\mathrm{p} \leq 0.05$ [14].

\section{Results and Discussion}

\subsection{TAC}

Three blends consisting of apple-carrot juice with ratios of 60:40, 75:25 and 90:10 were selected by a in-house informal evaluation (data not presented), were treated with ultrasound and thermal pasteurization treatments and stored at $4^{\circ} \mathrm{C}$ and room temperature for four weeks (Figure 1). Control juice samples (without ultrasound treatment or pasteurization) of all three juice blends stored in $4^{\circ} \mathrm{C}$ and room temperature were spoiled (TAC were more than $10^{7} \mathrm{CFU} / \mathrm{mL}$ juice) within 14 days. TAC of juice samples stored in $4^{\circ} \mathrm{C}$ was lower than those stored at room temperature. Up to day 14 , TAC of juice samples which contained higher apple juice percentage (apple-carrot ratio of 90:10 and 75:25, v/v) were lower 
$4^{\circ} \mathrm{C} \quad$ Room Temperature
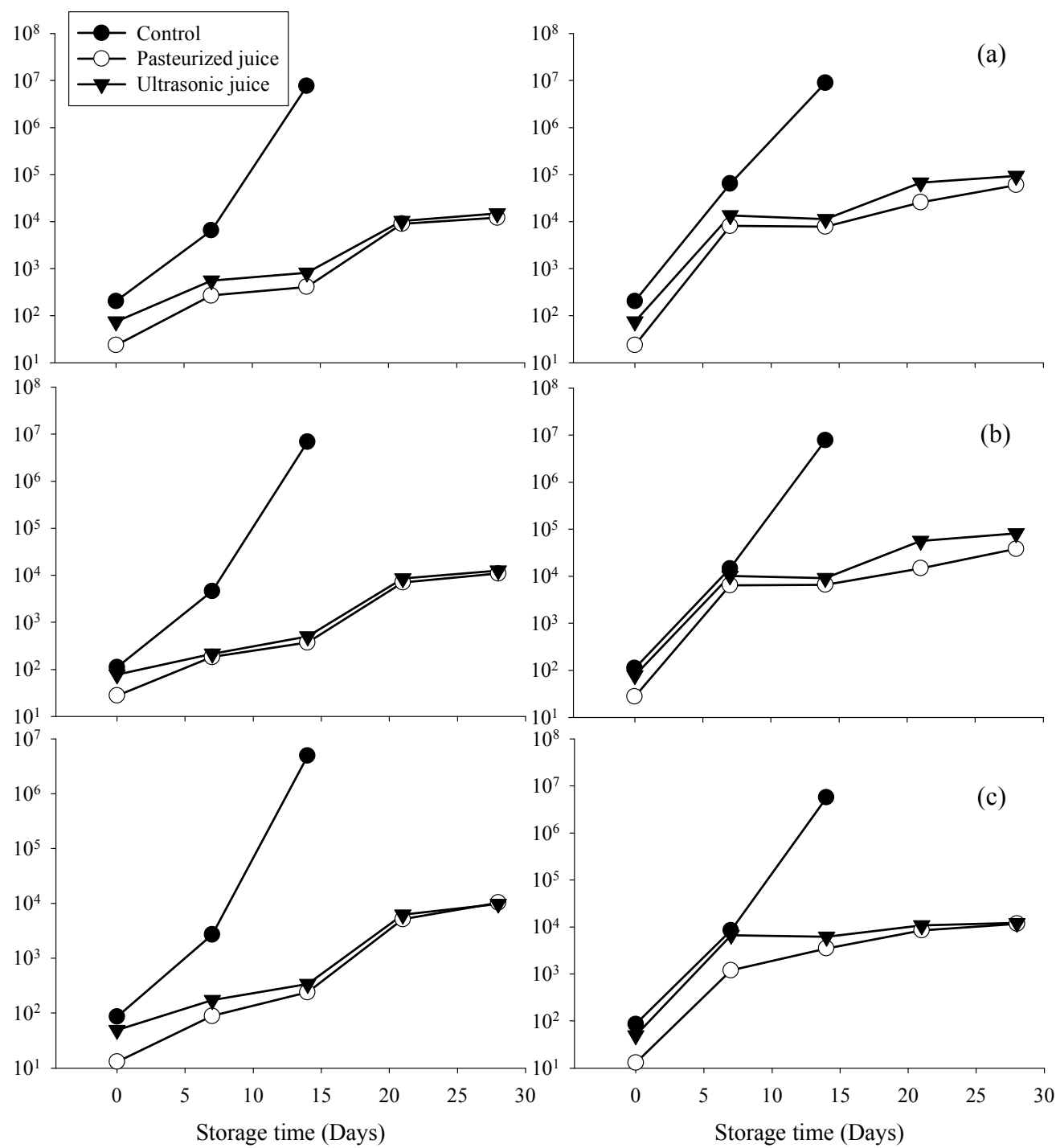

Figure 1. Changes of total aerobic counts (TAC, log CFU/mL) of three different apple-carrot ratios of 60:40 (a), 75:25 (b) and 90:10 (c) treated with pasteurization and ultrasonic technique compare to none treated juice stored at $4^{\circ} \mathrm{C}$ and room temperature.

than that of the blend contained lower apple juice percentage. The inhibitory effect on the bacterial growth caused by juice $\mathrm{pH}$ followed the $\mathrm{pH}$ tolerance for lactic acid bacteria [15]. In another study, a prolonged shelf life was observed by carbonating the carrot juice or adjusting carrot juice $\mathrm{pH}$ below $\mathrm{pH} 4$ using $\mathrm{HCl}$ [15]. Similarly, TAC of ultrasound-treated $\left(20 \mathrm{kHz}, 500 \mathrm{~W}, 10^{\circ} \mathrm{C}\right)$ orange juice stored at $4^{\circ} \mathrm{C}$ and $10^{\circ} \mathrm{C}$ reached $10^{6} \mathrm{CFU} / \mathrm{mL}$ within 10 days (Gomez-Lopez et al., 2010). The present results suggest that ultrasound treatment provided a similar microbial quality of the blends treated with thermal pasteurization. In support, when apple cider and milk were treated with ultrasound, E. coli $\mathrm{O} 157: \mathrm{H} 7$ and $L$. monocytogenes were reduced by 5 and $6 \log \mathrm{CFU} / \mathrm{mL}$, respectively [16].

The microbial growth in juice blends was related to the juice $\mathrm{pH}$. The effect of decreasing $\mathrm{pH}$ (carrot juice adjusted by $\mathrm{HCl}$ ) on the relative shelf life based on thermal power is marginal at $\mathrm{pH}$ above 4.5 [15]. There was some effect of $\mathrm{pH}$ between 4.5 and 4 , and below $\mathrm{pH} 4$, the shelf life was considerably prolonged [15]. Populations of Salmonella typhimurium in high inoculums $5.73 \mathrm{log}$ $\mathrm{CFU} / \mathrm{mL}$ ) were reduced by $2.68 \log \mathrm{CFU} / \mathrm{mL}$ after dipping carrots for 15 and $30 \mathrm{~min}$ in lemon juice $(4.46 \%$ citric acid, $\mathrm{v} / \mathrm{v}$ ) and a $3.95 \log \mathrm{CFU} / \mathrm{mL}$ reduction was achieved by dipping $60 \mathrm{~min}$ [15]. A reduction of $3.85 \mathrm{log}$ $\mathrm{CFU} / \mathrm{mL}$ S. typhimurium was observed at high inoculums by dipping carrots in vinegar $(4.03 \%$ acetic acid, $v / v)$ for 
60 min [17]. Dipping carrots in the mixture of lemon and vinegar $(1: 1)$ for $15 \mathrm{~min}$ resulted a reduction of $5 \mathrm{log}$ $\mathrm{CFU} / \mathrm{mL}$ of $S$. typhimurium [15]. Therefore, the microorganism growth could be inhibited and decreased by lower juice $\mathrm{pH}$.

\subsection{Chemical Characteristics of Apple-Carrot Juice Blends}

$\mathrm{pH}$, TA and TSS of the three blends were slightly different due to different apple-carrot juice ratios (Table 1). TA and TSS of juice blends with higher apple-carrot ratio $(90: 10, \mathrm{v} / \mathrm{v})$ were higher than that of juice blends of lower apple-carrot ratio of 75:25 and 60:40. All juice blends demonstrated the same pattern of increasing $\mathrm{pH}$, decreasing TA and decreasing TSS over storage period.
pH of juice blends (apple-carrot ratio of 60:40 and 75:25) significantly increased after 14 days of shelf life except for 75:25 apple-carrot juice blend which was treated with thermal pasteurization stored at $4^{\circ} \mathrm{C}$. The juice $\mathrm{pH}$ of the 90:10 apple-carrot ratio blend did not significantly change. TA of all blends showed a significant decrease when treated with either methods after seven days shelf life, except for 75:25 and 90:10 apple-carrot juice blends which were treated with thermal pasteurization. Similar to the present finding (Table 1), no trend was found in TSS, TA and $\mathrm{pH}$ value changes during 10 days storage of ultrasound-treated $(20 \mathrm{kHz}, 2-10 \mathrm{~min})$ orange juice [5]. No significant $(\mathrm{p}<0.05)$ differences of $\mathrm{pH}$, TSS and TA were also observed before and after ultrasound treatment of grape juice [18].

Table 1. Chemical characteristics of apple-carrot juice blends recorded during storage period at $4^{\circ} \mathrm{C}$.

\begin{tabular}{|c|c|c|c|c|c|c|c|}
\hline Apple: carrot ratio & & Time (Days) & $\mathrm{pH}$ & TA (mg MAE/100g juice) & TSS $(\%)$ & FRAP (mmol TE/L juice) & Beta Carotene $(\mathrm{mg} / \mathrm{L})$ \\
\hline \multirow[t]{9}{*}{$60: 40$} & $\mathrm{TP}$ & 0 & $3.99^{\mathrm{B}}$ & $396.4^{\mathrm{D}}$ & $9.80^{\mathrm{B}}$ & $354.5^{\mathrm{G}}$ & $27.2^{\mathrm{C}}$ \\
\hline & & 7 & $4.15^{\mathrm{B}}$ & $368.5^{\mathrm{E}}$ & $9.13^{\mathrm{B}}$ & $253.2^{\mathrm{J}}$ & $27.2^{\mathrm{C}}$ \\
\hline & & 14 & $4.86^{\mathrm{A}}$ & $463.4^{\mathrm{B}}$ & $8.97^{\mathrm{BC}}$ & $291.7^{\mathrm{I}}$ & $27.0^{\mathrm{C}}$ \\
\hline & & 21 & $4.73^{\mathrm{A}}$ & $240.1^{\mathrm{I}}$ & $8.79^{\mathrm{C}}$ & $290.4^{\mathrm{I}}$ & $26.8^{\mathrm{C}}$ \\
\hline & & 28 & $4.92^{\mathrm{A}}$ & $300.3^{\mathrm{G}}$ & $8.77^{\mathrm{C}}$ & $306.5^{\mathrm{H}}$ & $27.0^{\mathrm{C}}$ \\
\hline & & 7 & $5.06^{\mathrm{A}}$ & $385.2^{\mathrm{DE}}$ & $9.20^{\mathrm{B}}$ & $313.7^{\mathrm{H}}$ & $27.0^{\mathrm{C}}$ \\
\hline & & 14 & $4.96^{\mathrm{A}}$ & $332.0^{\mathrm{F}}$ & $9.33^{\mathrm{B}}$ & $344.1^{\mathrm{G}}$ & $26.9^{\mathrm{C}}$ \\
\hline & & 21 & $4.95^{\mathrm{A}}$ & $309.3^{\mathrm{G}}$ & $9.16^{\mathrm{B}}$ & $323.4^{\mathrm{H}}$ & $26.8^{\mathrm{C}}$ \\
\hline & & 28 & $5.07^{\mathrm{A}}$ & $298.1^{\mathrm{H}}$ & $8.81^{\mathrm{C}}$ & $286.5^{\mathrm{I}}$ & $30.7^{\mathrm{B}}$ \\
\hline \multirow[t]{9}{*}{$75: 25$} & $\mathrm{TP}$ & 0 & $3.69^{\mathrm{B}}$ & $377.4^{\mathrm{E}}$ & $9.57^{\mathrm{B}}$ & $457.9^{\mathrm{E}}$ & $31.5^{\mathrm{B}}$ \\
\hline & & 14 & $3.84^{\mathrm{B}}$ & $368.5^{\mathrm{E}}$ & $9.33^{\mathrm{B}}$ & $401.2^{\mathrm{F}}$ & $30.7^{\mathrm{B}}$ \\
\hline & & 21 & $4.51^{\mathrm{B}}$ & $369.6^{\mathrm{E}}$ & $9.18^{\mathrm{B}}$ & $380.6^{\mathrm{FG}}$ & $30.5^{\mathrm{B}}$ \\
\hline & & 28 & $4.11^{\mathrm{B}}$ & $351.7^{\mathrm{EF}}$ & $9.05^{\mathrm{B}}$ & $359.8^{\mathrm{G}}$ & $32.1^{\mathrm{B}}$ \\
\hline & US & 0 & $3.69^{\mathrm{B}}$ & $444.4^{\mathrm{C}}$ & $9.57^{\mathrm{B}}$ & $530.8^{\mathrm{C}}$ & $31.1^{\mathrm{B}}$ \\
\hline & & 7 & $4.86^{\mathrm{A}}$ & $408.7^{\mathrm{D}}$ & $9.23^{\mathrm{B}}$ & $403.7^{\mathrm{F}}$ & $30.6^{\mathrm{B}}$ \\
\hline & & 14 & $4.35^{\mathrm{B}}$ & $367.4^{\mathrm{E}}$ & $9.30^{\mathrm{B}}$ & $418.6^{\mathrm{F}}$ & $30.5^{\mathrm{B}}$ \\
\hline & & 21 & $4.67^{\mathrm{AB}}$ & $370.7^{\mathrm{E}}$ & $9.12^{\mathrm{B}}$ & $441.9^{\mathrm{E}}$ & $30.5^{\mathrm{B}}$ \\
\hline & & 28 & $4.81^{\mathrm{A}}$ & $374.1^{\mathrm{E}}$ & $9.11^{\mathrm{B}}$ & $446.5^{\mathrm{E}}$ & $30.8^{\mathrm{C}}$ \\
\hline \multirow[t]{9}{*}{$90: 10$} & $\mathrm{TP}$ & 0 & $3.45^{\mathrm{B}}$ & $404.2^{\mathrm{D}}$ & $10.97^{\mathrm{A}}$ & $664.8^{\mathrm{A}}$ & $42.9^{\mathrm{A}}$ \\
\hline & & 7 & $3.55^{\mathrm{B}}$ & $385.2^{\mathrm{DE}}$ & $11.03^{\mathrm{A}}$ & $625.1^{\mathrm{AB}}$ & $42.4^{\mathrm{A}}$ \\
\hline & & 14 & $3.57^{\mathrm{B}}$ & $394.2^{\mathrm{D}}$ & $10.73^{\mathrm{A}}$ & $625.9^{\mathrm{AB}}$ & $42.3^{\mathrm{A}}$ \\
\hline & & 28 & $3.71^{\mathrm{B}}$ & $385.3^{\mathrm{DE}}$ & $10.28^{\mathrm{AB}}$ & $513.6^{\mathrm{D}}$ & $40.1^{\mathrm{A}}$ \\
\hline & US & 0 & $3.43^{\mathrm{B}}$ & $495.3^{\mathrm{A}}$ & $10.90^{\mathrm{A}}$ & $653.4^{\mathrm{A}}$ & $42.6^{\mathrm{A}}$ \\
\hline & & 7 & $3.61^{\mathrm{B}}$ & $360.7^{\mathrm{E}}$ & $11.03^{\mathrm{A}}$ & $633.5^{\mathrm{A}}$ & $42.3^{\mathrm{A}}$ \\
\hline & & 14 & $3.72^{\mathrm{B}}$ & $399.7^{\mathrm{D}}$ & $10.63^{\mathrm{AB}}$ & $646.5^{\mathrm{A}}$ & $42.2^{\mathrm{A}}$ \\
\hline & & 21 & $3.74^{\mathrm{B}}$ & $393.1^{\mathrm{D}}$ & $10.39^{\mathrm{AB}}$ & $623.8^{\mathrm{AB}}$ & $42.1^{\mathrm{A}}$ \\
\hline & & 28 & $3.87^{\mathrm{B}}$ & $397.5^{\mathrm{D}}$ & $10.38^{\mathrm{AB}}$ & $471.0^{\mathrm{DE}}$ & $42.2^{\mathrm{A}}$ \\
\hline
\end{tabular}

A-J Means followed by the same letter within each column are not significantly different (factorial test, $\mathrm{n}=3$, $\mathrm{p}<0.05$ ); TP: thermal pasteurization; US: ultrasonic technique; MAE: malic acid equivalence. 
The juice blend of the highest apple-carrot ratio (90:10) had the highest antioxidant capacity and the lowest apple-carrot ratio blend (60:40) had the lowest antioxidant capacity (Table 1). The antioxidant capacity of juice blend of 60:40 and 75:25 (apple-carrot ratio, v/v) demonstrated significant decline after seven days of shelf life. However, the antioxidant capacity of juice blends of 90:10 (apple-carrot ratio, v/v) did not show significant decrease until 28 days of shelf life. The antioxidant capacity of these juice blends is related to the amount and composition of phytochemicals such as phenolic acids, flavonoids, carotenoids and vitamins. Interestingly, antioxidant capacity of juice blends was not affected by the two method of pasteurization.

Beta-carotene content of different juice blends (apple-carrot ratio of $60: 40,75: 25$ and $90: 10, \mathrm{v} / \mathrm{v}$ ) varied from 26.8 to $42.6 \mathrm{mg} / 100 \mathrm{~g}$ juice (Table 1). Beta-caro- tene content remained stable and did not show statistically significant changes $(p \leq 0.05)$ during four weeks of storage after ultrasound treatment or thermal pasteurization (Table 1). However, when the effects of ultrasound exposure on beta-carotene were investigated using different solvents, increase in beta-carotene degradation was observed with increasing intensity of ultrasound $[19,20]$.

\subsection{Physical Characteristics of Apple-Carrot Juice Blends}

The turbidity of the juice blends of apple-carrot ratio $(90: 10, \mathrm{v} / \mathrm{v})$ was the lowest and the turbidity of the juice blends of apple-carrot ratio $(60: 40, \mathrm{v} / \mathrm{v})$ was the highest (Table 2). This could be also due to more solid particles in the carrot juice when compared with apple juice. The

Table 2. Physical characteristics of apple-carrot juice blends during storage period at $4^{\circ} \mathrm{C}$.

\begin{tabular}{|c|c|c|c|c|c|c|c|c|}
\hline \multirow{2}{*}{ Apple-carrot ratio } & & \multirow{2}{*}{ Time (Days) } & \multirow{2}{*}{ Turbidity (NTU) } & \multicolumn{3}{|c|}{ Colour } & \multirow[b]{2}{*}{ Hue } & \multirow[b]{2}{*}{ Chroma } \\
\hline & & & & $\mathrm{L}^{*}$ & $a^{*}$ & $b^{*}$ & & \\
\hline \multirow[t]{8}{*}{$60: 40$} & $\mathrm{TP}$ & 0 & $1896^{\mathrm{C}}$ & 50.00 & 15.26 & 31.03 & 0.49 & 34.6 \\
\hline & & 14 & $2147^{\mathrm{C}}$ & 55.38 & 17.19 & 36.36 & 0.47 & 40.2 \\
\hline & & 21 & $2659^{\mathrm{B}}$ & 46.49 & 18.83 & 31.72 & 0.59 & 36.9 \\
\hline & US & 0 & $2161^{\mathrm{C}}$ & 54.75 & 19.01 & 34.75 & 0.55 & 39.6 \\
\hline & & 7 & $1890^{\mathrm{C}}$ & 54.10 & 17.26 & 40.31 & 0.43 & 43.8 \\
\hline & & 14 & $2120^{\mathrm{C}}$ & 59.09 & 13.07 & 30.59 & 0.43 & 33.3 \\
\hline & & 21 & $2822^{\mathrm{B}}$ & 47.94 & 16.94 & 33.06 & 0.51 & 37.1 \\
\hline & & 28 & $3112^{\mathrm{A}}$ & 46.84 & 15.32 & 37.32 & 0.41 & 40.3 \\
\hline \multirow[t]{10}{*}{$75: 25$} & $\mathrm{TP}$ & 0 & $1439^{\mathrm{DE}}$ & 57.00 & 14.76 & 29.43 & 0.50 & 32.9 \\
\hline & & 7 & $1418^{\mathrm{E}}$ & 61.67 & 11.80 & 29.67 & 0.40 & 31.9 \\
\hline & & 14 & $1432^{\mathrm{E}}$ & 51.78 & 14.75 & 29.90 & 0.49 & 33.3 \\
\hline & & 21 & $1604^{\mathrm{D}}$ & 49.08 & 15.46 & 22.90 & 0.68 & 27.6 \\
\hline & & 28 & $1780^{\mathrm{C}}$ & 51.48 & 16.63 & 35.55 & 0.47 & 39.2 \\
\hline & US & 0 & $1257^{\mathrm{F}}$ & 55.27 & 15.65 & 31.15 & 0.50 & 34.9 \\
\hline & & 7 & $1064^{\mathrm{G}}$ & 63.52 & 11.02 & 30.66 & 0.36 & 32.6 \\
\hline & & 14 & $1488^{\mathrm{D}}$ & 48.15 & 18.45 & 36.57 & 0.50 & 41.0 \\
\hline & & 21 & $1512^{\mathrm{D}}$ & 46.70 & 16.33 & 34.33 & 0.48 & 38.0 \\
\hline & & 28 & $1886^{\mathrm{C}}$ & 42.25 & 15.95 & 36.13 & 0.44 & 39.5 \\
\hline \multirow[t]{9}{*}{$90: 10$} & $\mathrm{TP}$ & 0 & $563^{\mathrm{I}}$ & 63.69 & 6.24 & 19.78 & 0.32 & 20.7 \\
\hline & & 7 & $564^{\mathrm{I}}$ & 61.24 & 8.63 & 30.20 & 0.29 & 31.4 \\
\hline & & 14 & $598^{\mathrm{H}}$ & 78.83 & 2.61 & 16.15 & 0.16 & 16.4 \\
\hline & & 21 & $586^{\mathrm{H}}$ & 59.96 & 9.46 & 31.81 & 0.30 & 33.2 \\
\hline & US & 0 & $555^{\mathrm{I}}$ & 59.97 & 9.76 & 21.59 & 0.45 & 23.7 \\
\hline & & 7 & $559^{\mathrm{I}}$ & 63.55 & 7.83 & 30.30 & 0.26 & 31.3 \\
\hline & & 14 & $595^{\mathrm{H}}$ & 74.79 & 4.38 & 21.48 & 0.20 & 21.9 \\
\hline & & 21 & $581^{\mathrm{H}}$ & 61.06 & 8.79 & 31.82 & 0.28 & 33.0 \\
\hline & & 28 & $629^{\mathrm{H}}$ & 59.80 & 8.84 & 31.27 & 0.28 & 32.5 \\
\hline
\end{tabular}

A-C Means followed by the same letter within each column are not significantly different (factorial test, $\mathrm{n}=3$, $\mathrm{p}<0.05$ ); TP: thermal pasteurization; US: ultrasonic technique. 
turbidity of the juice blends increased during storage, which may be due to the increase in the microorganism growth indicated by TAC (Table 2). Turbidity significantly increased after 21 days of storage in all juice blends treated with both ultrasound treatment and thermal pasteurization. Colour did not change significantly in relation to the treatments or the storage time (Table 2). In contrast, an increase in lightness ( $\left.\mathrm{L}^{*}\right)$ and red green value $\left(a^{*}\right)$ and a decrease in blue yellow value $\left(b^{*}\right)$ was observed in ultrasound-treated grape juice compare with the non-treated juice [17].

\section{Conclusion}

There was no difference of TAC of apple-carrot juice blends when treated with the ultrasound treatment or traditional thermal pasteurization. On day 14 of storage, there was a significant decrease of TAC of both ultrasound-treated and pasteurized juice blends compared to non-treated (control) juice suggesting that ultrasound treatment has potential to use in commercial juice manufacturing. When the ratio of apple-carrot juice was higher, the juice $\mathrm{pH}$, and TAC were lower. The juice blend of the highest apple-carrot ratio $(90: 10)$ had the highest TA, TSS and antioxidant capacity compared to the other blends with the lower amount of apple juice. However, further investigations are required for assessing the sensory attributes of blends of various apple-carrot juice ratios. In general, acidification of carrot juice by blending with apple juice and application of ultrasound treatment as a potential non-thermal pasteurization method for liquid foods can be suggested.

\section{Acknowledgements}

The financial support of this project was provided by J. W. Mason and Sons Limited, Windsor, NS, Canada and the Atlantic Innovation Fund (AIF) of Atlantic Canada Opportunity Agency (ACOA).

\section{REFERENCES}

[1] H. K. Sharma, J. Kaur, B. C. Sarkar, C. Singh and B. Singh, "Effect of Pretreatment Conditions on Physic chemical Parameters of Carrot Juice," International Journal of Food Science and Technology, Vol. 44, No. 1, 2009, pp. 1-9. doi:10.1111/j.1365-2621.2006.01462.x

[2] N. Demir, J. Acer and K. S. Bahceci, "Effects of Storage on Quality of Carrot Juices Produced with Lactofermentation and Acidification," European Food Research and Technology, Vol. 218, No. 5, 2004, pp. 465-468. doi:10.1007/s00217-004-0883-8

[3] W. S. Kim and S. Y. Kim, "Effect of Blanching Condition, Acid and Alkali Treatments on the Qualities, of Carrot Juice," Research Report, Agricultural Science and Te- chnology, Chungnam National University of Korean, Vol. 10, No. 1, 1983, pp. 135-145.
[4] A. O. Adekunte, B. K. Tiwari, P. J. Cullen, A. G. M. Scannell and C. P. O'Donnell, "Effect of Sonication on Colour, Ascorbic Acid and Yeast Inactivation in Tomato Juice," Food Chemistry, Vol. 122, No. 3, 2010, pp. 500507. doi:10.1016/j.foodchem.2010.01.026

[5] V. M. Gomez-Lopez, L. Orsolani, A. Martinez-Yepez and M. S. Tapia, "Microbilogical and Sensory Quality of Sonicated Calcium-Added Orange Juice," LWT_Food Science and Technology, Vol. 43, No. 5, 2010, pp. 808-813.

[6] A. R. Baumann, S. E. Martin and H. Feng, "Power Ultrasound Treatment of Listeria monocytogenes in Apple Cider," Journal of Food Protection, Vol. 68, No. 11, 2005, pp. 2333-2340.

[7] S. Patil, P. Bourke, B. Kelly, J. M. Frias and P. J. Cullen, "The Effects of Acid Adaptation on Escherichia coli inactivation Using Power Ultrasound," Innovative Food Science and Emerging Technologies, Vol. 10, No. 4, 2009 , pp. 486-490. doi:10.1016/j.ifset.2009.06.005

[8] C. P. O'Donnell, B. K. Tiwari, P. Bourke and P. J. Cullen, "Effect of Ultrasonic Processing on Food Enzymes of Industrial Importance," Trends in Food Science and Technology, Vol. 21, No. 7, 2010, pp. 358-367. doi:10.1016/j.tifs.2010.04.007

[9] J. M. Lopez-Nicolas and F. Garcia-Carmona, "Use of Cyclodextrins as Secondary Antioxidants to Improve the Color of Fresh Pear Juice," Journal of Agricultural and Food Chemistry, Vol. 55, No. 15, 2007, pp. 6330-6338. doi:10.1021/jf070819x

[10] B. H. Chen, H. Y. Peng and H. E. Chen, "Changes of Carotenoids, Color, and Vitamin A Contents during Processing of Carrot Juice," Journal of Agricultural and Food Chemistry, Vol. 43, No. 7, 1995, pp. 1912-1918. doi:10.1021/jf00055a029

[11] C. Ratnasooriya, H. P. V. Rupasinghe and A. Jamieson, "Juice Quality and Polyphenol Concentration of Fresh Fruits and Pomace of Selected Nova Scotia-Grown Grape Cultivars," Canadian Journal of Plant Science, Vol. 90, No. 2, 2010, pp. 193-205. doi:10.4141/CJPS09137

[12] I. F. F. Benzie and J. J. Strain, "The Ferric Reducing Ability of Plasma (FRAP) as a Measure of "Antioxidant Power': The FRAP Assay," Analytical Biochemistry, Vol. 239, No. 1, 1996, pp. 70-76. doi:10.1006/abio.1996.0292

[13] H. P. V. Rupasinghe, G. M. Huber, C. G. Embree and P. L. Forsline, "Red-Fleshed Apple as a Source for Functional Beverages," Canadian Journal of Plant Science, Vol. 90, 2010, pp. 95-100. doi:10.4141/CJPS09057

[14] SAS Institute Inc., Cary, NC, USA, 1999. http://www.hoovers.com/company/SAS_Institute_Inc/ctcj ri-1.html

[15] C. Alklint, L. Wadso and I. Sjoholm, "Effects of Modified Atmosphere on Shelf-Life of Carrot Juice," Food Control, Vol. 15, No. 2, 2004, pp. 131-137. doi:10.1016/S0956-7135(03)00024-0

[16] R. M. Corbo, A. Bevilacqua, D. Campaniello, D. D'Amato, B. Speranza and M. Sinigaglia, "Prolonging Microbial Shelf Life of Foods through the Use of Natural Compounds and Non-Thermal Approaches-A Review," International Journal of Food Science and Technology, Vol. 44, No. 2, 2009, 
pp. $223-241$.

doi:10.1111/j.1365-2621.2008.01883.X

[17] I. Y. Sengun and M. Karapinar, "Effectiveness of Lemon Juice, Vinegar and Their Mixture in Elimination of Salmonella typhimurium on Carrots (Daucus carota L.)," International Journal of Food Microbiology, Vol. 96, 2004, pp. 301-305. doi:10.1016/j.ijfoodmicro.2004.04.010

[18] B. K. Tiwari, C. P. O'Donnell and P. J. Cullen, "Effect of Non Thermal Processing Technologies on the Anthocyanin Content of Fruit Juices," Trends in Food Science and Technology, Vol. 20, No. 3-4, 2009, pp. 137-145. doi:10.1016/j.tifs.2009.01.058

[19] Y. Sun, G. Ma, X. Ye, Y. Kakuda and R. Meng, "Stability of All-Trans- $\beta$-Carotene under Ultrasound Treatment in a Model System: Effects of Different Factors, Kinetics and Newly Formed Compounds," Ultrasonics Sonochemistry, Vol. 17, No. 4, 2010, pp. 654-661. doi:10.1016/j.ultsonch.2009.12.005

[20] A. S. Malik, O. Boyko, N. Atkar and W. F. Young, “A Comparative Study of MR Imaging Profile of Titanium Pedicle Screws," Acta Radiologica, Vol. 42, No. 3, 2001, pp. 291-293. doi: $10.1080 / 028418501127346846$ 